\title{
魚類筋肉の解糖作用汇関する酵素学的矼究一 $\mathrm{N}$.
}

$$
\text { 筋肉フォスフォリラーゼの特性 }
$$

永山文男

(1961 年 10 月 5 日受理)

\section{ENZYMATIC STUDIES ON THE GLYCOLYSIS IN FISH MUSCLE-IV. SOME SPECIFICITIES OF MUSCLE PHOSPHORYLASE \\ Fumio NagaYama*}

Separation and purification of muscle phosphorylase from seabass were tried, and some specificities of the emzyme were investigated.

The enzyme preparation showed the specific activity twenty times higher than the crude muscle extract, but the enzyme was not obtained in crystalline form. It was considered that the total activity of phosphorylase in the muscle of seabass is one fourteenth of the phosphorylase content in rabbit muscle.

The enzyme of seabass showed the maximum activity at $37^{\circ} \mathrm{C}$, although the enzyme of rainbow trout showed the maximum activity at $25^{\circ} \mathrm{C}$. The existences of two types of phosphorylase, $a$ and $b$, were demonstrated by the experiment with the effect of adenylic acid $\left(5^{\prime}-\right.$ AMP). Starch and $3^{\prime}$-AMP did not induce the enzyme action.

第 I 報”に拈いて，スズキ筋肉の抽出液について，グリコーゲン分解能からそのフォスフォリラーゼ作用 を推定したが，さらに細かい特性を明らかにするために醉素の精製を試み，その二三丨性質を明らかにし た。

\section{実験試料および方法}

試料＼cjkstart第皿報と同様にスズキの活魚を供試した。

醂素調紫法 GREEN ら ${ }^{2)}$ の方法に準じた。すなわち，原料筋肉を等容の冷蒸留水で 2 回抽出し， $\mathrm{HCl}$ で pH 6.4 にして流水に透析する。これを $\mathrm{pH} 6.0$ にし遠心分離し沈澱を除く。上澄を $\mathrm{KHCO}_{8}$ で $\mathrm{pH}$ 6.9 Kし， pH 6.9 の飽和硫安液で 0.41 (または 0.45) 飽和にし遠心分離する。沈汼を蒸留水に溶かし流 水に透析後, $\mathrm{pH} 6.8$ のシスティングリセロリン酸ソーダ緩衝液に透析する。この液を0.41（または0.45） 飽和区とする。また 0.41 飽和時の上澄にさらに硫努を加党 0.65 (または 0.75) 飽和にしたとき生じた沈

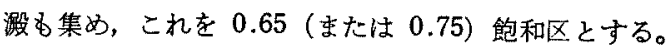

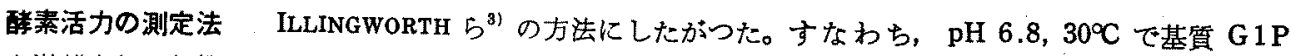
から遊離される與機リン酸の䁷によつて酵素活力を求めた。

基質の G1P は MCCREADY の万法" で醉素的に合成した。また酵素液の蛋白質濃度は FoLIN の比色 法 ${ }^{5)}$ か紫外吸取法

実験結果および考宗

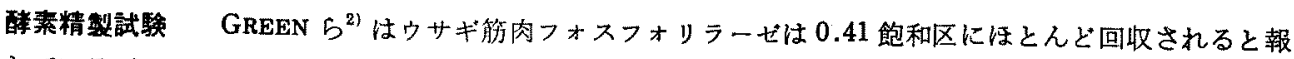
告しているが，スズキの筋肉を用いた本実験では，0.45 飽和沈澱を除いた後の上澄液から 0.65 あるいは

*東京水産大学 (Tokyo Univ. of Fish,, Shiba Kaigandori 6, Minato-ku, Tokyo). 
0.75 飽和沈澱を集めてみると,かなりのフォスフォリラーゼ活力が認められた。

精謷試験の一例を Table 1 に示した。すなわち，原抽出液中に含まれるフォスフォリラーゼの約 40\%

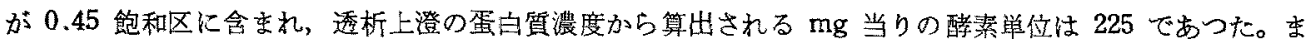
た原抽出液中の酵紫の䄪 $30 \%$ が 0.65 飽和区に回収されたが，この分画の $\mathrm{mg}$ 当りの酵菜単位は 16 で， 夾雑蛋白が多いものであつた。

Table 1. Fractionation of muscle phosphorylase from seabass. $500 \mathrm{~g}$. of the muscle was used.

\begin{tabular}{c|c|c|c|c|c}
\hline \hline \multicolumn{1}{c|}{ Fraction } & Volume $\mathrm{ml}$ & $k \times 10^{3} / \mathrm{m} l$ & $k \times 10^{3} / \mathrm{mg}$ & Total units & Recovery \\
\hline Crude extract & 1,000 & 145 & - & 145,000 & 100 \\
0.45 fraction* & 20 & 2,775 & 225 & 55,500 & 38.3 \\
0.65 fraction** & 60 & 685 & 16.0 & 41,100 & 28.3 \\
\hline
\end{tabular}

* Ppt. at 0.45 saturation of ammonium sulfate.

** Ppt. at 0.65 saturation of ammonium sulfate after removal of 0.45 fraction.

*** phosphorylase activity.

ウサギの後肢筋肉 $100 \mathrm{~g}$. から，CORI ${ }^{71}$ は $\mathrm{mg}$ 当り 2.515 単位の結晶フォスフォリラーゼ a を $40 \sim 80 \mathrm{mg}$, $\mathrm{FISCHER}^{8 /}$ は 1,580 単位の結晶フォスフォリラーゼbを $290 \mathrm{mg}$ 得たと報告して扔り，本奏験の結果とは かなりの差がある。しかし FISCHER の原抽出液がスズキの場合の約 14 倍の醉素量を含む点から，原料筋 肉の醅案含量が買なるすのと思われる。

結晶化はできなかつたが，魚肉の酵素特性を観察するには充分と考光，以下の実駼には随時上記の上5に 調慗した醉素液を用いた。

アテニル酸の影響 フォスフォリラーゼには $\mathrm{a}, \mathrm{b} の 2$ 種があり， $\mathrm{a}$ 型は $\mathrm{b}$ 型 2 分子とリン酸の結合し たもので，PR (phosphorylase rupturing) 醅素により分解されると b 型になる キナーゼと ATP により a 型に再生される ${ }^{11}$ 。a, b 両型ともアデニル酸 $\left(5^{\prime}-\mathrm{AMP}\right)$ により賦活されるが, a 型はアデニル酸がなくても 60〜70\%の活性を見わし，b 型はアデニル酸がないとはとんど活性を現的さ ない ${ }^{10}$ 。確証はないが筋肉が疲労すると一畤的に $\mathrm{a} \rightarrow \mathrm{b}$ の区応が起こり，筋肉グリコーゲンが保持される あのであるると考党られている。

スズキのフォスフォリラーゼに対するアデニル酸の影響をみると,Fig. 1 のようにアデニル酸の賦活作用 は明らかであつた。すなわら Table 2 の実験 I の項からもみられるよ5に0.41 飽和区の大部分は、型, 0.75 枹和区のほとえどはb型の性質を示した。しかし Table 2 の夹験 II の場合には, 0.45 飽和区る 0.65 飽和区るフデニル酸なしにかなりの活性を示し、a 型の含量が多いと思われた。したがつて $\mathrm{a}, \mathrm{b}$ 兩型の存

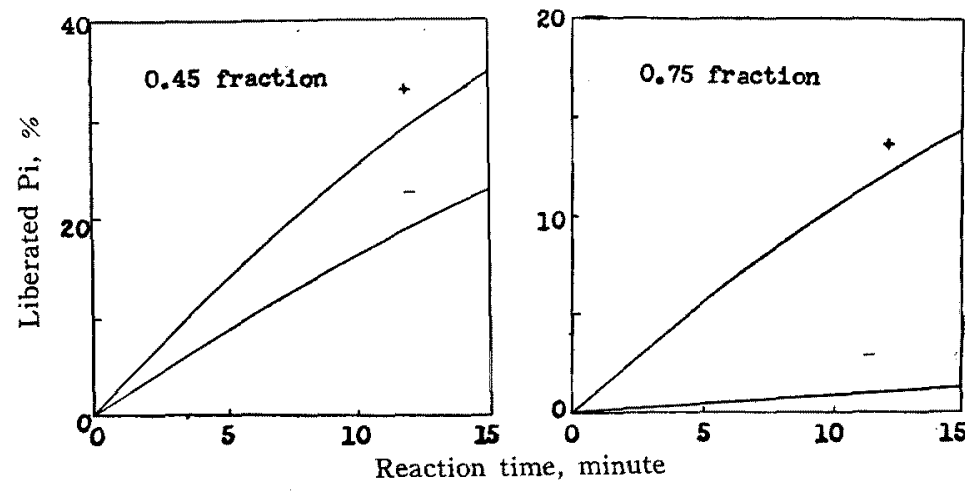

Fig. 1. Effect of adenylic acid on the muscle phosphorylase of seabass. Activity of the enzyme was determined at $\mathrm{pH} 6.8$, $30^{\circ} \mathrm{C}$, in the presence $(+)$ or the absence $(-)$ of adenylic acid. 
Table 2. Effect of adenylic acid on the muscle phosphorylase of seabass. The enzyme activity was determined at $\mathrm{pH} 6.8,30^{\circ} \mathrm{C}$, and was expressed as $k \times 10^{8}$.

\begin{tabular}{|c|c|c|c|c|}
\hline \multirow{2}{*}{$\begin{array}{c}\text { Experiment } \\
\text { No. }\end{array}$} & \multirow{2}{*}{ Fraction } & \multicolumn{2}{|c|}{ Adenylic acid } & \multirow{2}{*}{$\begin{array}{c}\text { Ratio } \\
-1+, \%\end{array}$} \\
\hline & & + & - & \\
\hline \multirow{2}{*}{ I } & 0.41 fraction $*$ & 17.5 & 9.88 & 57.1 \\
\hline & $0.75 \quad$ " $\quad * *$ & 35.2 & 2.12 & 6.02 \\
\hline \multirow{2}{*}{ II } & $0.45 \quad \| \quad * * * *$ & 44.0 & 17.9 & 40.7 \\
\hline & $0.65 \quad$ " ***** & 40.6 & 23.8 & 58.6 \\
\hline
\end{tabular}

在比は調慗操作中にも変動すると考㝋なければならない。

5'-AMP の代わりに 3'-AMP を添加しても賦活は全く認められなかつた。またグリコーゲンを添加しな いと G1P から算機りン酸を遊離せずグリコーゲンの代わりに植物澱粉を加光てす全く反応は起こらなか つた。

以上の諸点から，スズキの筋肉フォスフォリラーゼも，ウサギの筋肉フォスフォリラーゼと同様に， $5^{\prime}$ AMP の共存下にグリコーゲンの合成分解意触媒し，a 型と b 型が存在することが認められた。

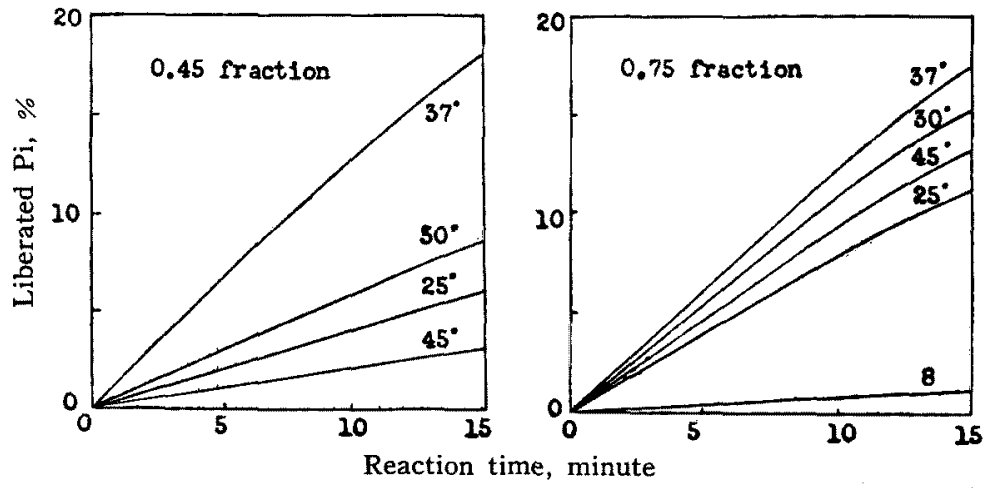

Fig. 2. Effect of temperature on the muscle phosphorylase of seabass.

温度の影讋＼cjkstart温度特性をみると Fig. 2 特よび Table 3 のよ 万に, $37^{\circ}$ でるとる大きな活力を 示し、をれより高温で歹低温で活力は小さからた。 特に 0.45 飽和区が 0.75 飽和区より 温度による 影響が顕著であるが，これは夾雑蛋白の有無による と思われる。

魚類の生活璒境の温度は哺乳動物のそれより $10^{\circ}$

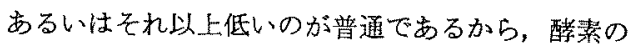
至適温度も低いことが予想されるのであるが，徽生 物あるい哺乳動物の酔装などが高い活力を示す $45^{\circ}$ において，スズキのフォスフォリラーゼが著し い失活京したのは当然であろう。
Table 3. Effect of temperature on the muscle phosphorylase of seabass.

\begin{tabular}{c|c|c|c|c}
\hline \multirow{2}{*}{$\begin{array}{l}\text { Tempera- } \\
\text { ture } \\
{ }^{\circ} \mathrm{C}\end{array}$} & \multicolumn{2}{|c|}{0.45 fraction* } & \multicolumn{2}{|c|}{0.75 fraction** } \\
\cline { 2 - 5 } & $k \times 10^{3}$ & $\begin{array}{r}\text { Relative } \\
\text { activity, } \\
\%\end{array}$ & $k \times 10^{3}$ & $\begin{array}{c}\text { Relative } \\
\text { activity, } \\
\%\end{array}$ \\
\hline 8 & - & - & 2.0 & 5.6 \\
25 & 2.35 & 70 & 23.8 & 67 \\
30 & 3.38 & 100 & 35.2 & 100 \\
37 & 7.82 & 230 & 41.0 & 117 \\
45 & 1.19 & 35 & 29.9 & 84 \\
\hline$*$
\end{tabular}

さらにこの点を明確にするために，冷水性魚類であるニジマスの筋肉フォスフォリラーゼの温度特性をみ 


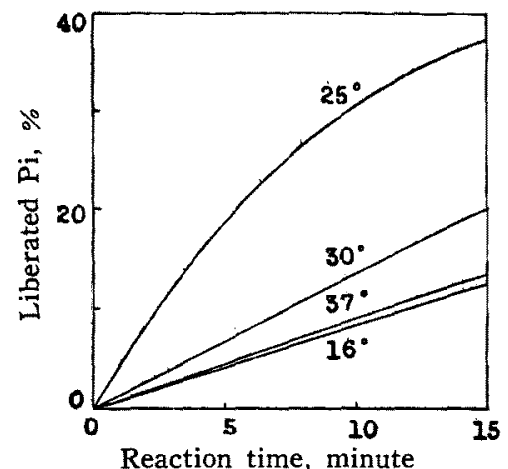

Fig. 3. Effect of temperature on the muscle phosphorylase of rainbow trout.
Table 4. Effects of reagents on the muscle phosphorylase of seabass.

\begin{tabular}{l|c|c|c}
\hline \hline \multirow{2}{*}{ Additive } & $\begin{array}{c}\text { Concentration } \\
\mathrm{M}\end{array}$ & \multicolumn{2}{|c}{$k \times 10^{3}$} \\
\cline { 2 - 4 } & $\begin{array}{c}0.45^{*} \\
\text { fraction }\end{array}$ & $\begin{array}{c}0.65^{* *} \\
\text { fraction }\end{array}$ \\
\hline $\mathrm{None}$ & - & 41.3 & 27.9 \\
$\mathrm{NaF}$ & 0.0125 & 43.3 & - \\
$\mathrm{MgCl}_{2}$ & 0.0125 & 39.8 & 37.6 \\
$\mathrm{CH}_{2} \mathrm{ICOOH}$ & 0.0125 & 0 & 0 \\
\multicolumn{1}{|c}{} & 0.00125 & 38.2 & 19.8 \\
$\mathrm{NaCl}$ & 0.5 & 36.1 & 12.6 \\
\hline$* \times 50$, & $* * \times 20$ & &
\end{tabular}

ると Fig. 3 のよ5に, 至適温度は $25^{\circ}$ であつた。

このように醇素の温度特性が生活嘪境によつて異なり，

反応の至適温度が実際の生活環境よりやや高めの点にあることは, 広義の自己消化を考虑する漁獲物処理の 面で充分留意されなければならない。しかしいずれの場合にも，ごく低温で忧反応が阻止または抑制される ことも明らかである。

莱品の影響数種の薬品の影響について観察し Table 4 の結果を得た。 $0.125 \mathrm{M} \mathrm{NaF}$ はやや賦活作用 を示し, $0.125 \mathrm{M} \mathrm{MgCl}_{2}$ は 0.45 飽和区ではやや抑制するよろにみ光るが 0.65 飽和区では反応を促進し た。0.5 M の $\mathrm{NaCl}$ は抑制効果を示した。またヨード酶酸は $0.0125 \mathrm{M} て ゙$ て完全に反応を抑光たが $0.00125 \mathrm{M}$ ではその协果は小さかつた。

これら薬品の影響はウサギの筋肉フォスフォリラーぜの場合に類似するものである。

要約

1.スズキの筋肉フォスフォリラーゼの精彆を試み，原抽出液の約 20 倍の比活性をるつ標品を得た。

2. 至適温度は $37^{\circ}$ 付近で, フテ゚ニル酸の影響から a, b 両型の存在が認められた。

3. 種々の薬品の影響からもスズキ筋肉フォスフォリラーゼはウサギの筋肉フォスフォリラーゼと類似の 性質をるつるのと思方れた。

本実験にご指導睗わつた九州大学富山折夫教授, 東京水産大学小野豊樹教授、ならびに実験に協力された 塚田新一，友松茂の両氏に感謝の意を表する。

\section{文献}

1）小野豊樹・永山文男：本誌，23，260 (1957).

2) A. A. Green and G. T. Cori: J. Biol. Chem., 151, 21 (1943).

3) B. ILlingworth and G. T. CoRI: Biochem. Prepn., 3, 1 (1953).

4) R. M. MC CREADY: ibid., 4, 63 (1955).

5) O. H. Lowry, N. J. Rosebrough, A. L. FarR and R. J. Randall: J. Biol. Chem., 193, 265 (1951).

6) O. Warburg and W. Christian: Biochem. Zeits., 310, 384 (1941).

7) G. T. CoRI: J. Bial. Chem., 158, 333 (1945).

8) E. H. FisCher and E. G. KREBS: ibid., 231, 231, 65 (1958).

9) E. G. Krebs, A. B. Kent and E. H. Fischer: ibid., 231, 73 (1958).

10) G. T. CoRI and A. A. GreEn: ibid., 151, 31 (1943).

11) E. G. KREBS and E. H. Fischer: Biochim. Biophys. Acta, 20, 150 (1956). 